\title{
INVESTIGATING THE USE OF METADISCOURSE MARKERS BY AMERICAN AND INDONESIAN WRITERS IN OPINION AND BUSINESS ARTICLES
}

\author{
Ardi Nugroho* \\ English Language and Culture Department, Bunda Mulia University \\ Received on 23 March 2020 / Approved on 3 April 2020
}

\begin{abstract}
Metadiscourse is an integral element of writing since it helps writers to organize and shape their arguments, but at the same time reflect their stance towards both the content and readers. There have been numerous studies concerning metadiscourse markers. However, little research has been done where Americans are directly compared with Indonesians. Furthermore, most of them have focused more on opinion, editorial, and sport articles, but not many have examined business ones. Considering this situation, the writer has become interested in investigating whether there are similarities and differences between how American and Indonesian writers incorporate metadiscourse markers in their opinion and business articles. The data for this research is taken from articles from two online newspapers, i.e. Washington Examiner and The Jakarta Post with a corpus size of 7,000 words for each type of article. The AntConc software version 3.5.6 by Anthony (2018) is used to analyze the data. The findings of the study reveal that there are some similarities and differences in the way American and Indonesian writers employ these markers in the writing of opinion and business articles. Keywords: metadiscourse markers, opinion and business articles, American and Indonesian writers
\end{abstract}

\section{ABSTRAK}

Metadiscourse adalah elemen penting dalam penulisan karena membantu penulis untuk mengatur dan membentuk argumen mereka, dan sekaligus mencerminkan sikap mereka terhadap konten dan pembaca. Ada banyak penelitian tentang penanda metadiscourse. Namun, sedikit penelitian yang telah dilakukan di mana orang Amerika dibandingkan dengan orang Indonesia secara langsung. Selain itu, sebagian besar dari mereka lebih fokus pada artikel opini, editorial, dan olahraga, tetapi tidak banyak yang meneliti artikel bisnis. Mempertimbangkan situasi ini, penulis menjadi tertarik untuk menyelidiki apakah ada persamaan dan perbedaan antara bagaimana penulis Amerika dan Indonesia menggunakan penanda metadiscourse dalam artikel opini dan bisnis mereka. Data untuk penelitian ini diambil dari artikel dari dua surat kabar online, yaitu Washington Examiner dan The Jakarta Post dengan ukuran korpus sebesar 7.000 kata untuk setiap jenis artikel. Perangkat lunak AntConc versi 3.5.6 oleh Anthony (2018) digunakan untuk menganalisis datanya. Temuan penelitian ini menunjukkan bahwa ada beberapa persamaan dan perbedaan dalam cara penulis Amerika dan Indonesia menggunakan penanda ini dalam penulisan artikel opini dan bisnis.

Kata Kunci: penanda metadiscourse, artikel opini dan bisnis, penulis Amerika dan Indonesia

\section{INTRODUCTION}

Spoken conversations generally involve the negotiation of meaning between the hearer and the speaker. It is the role of the hearer to correctly interpret the meaning behind the speaker's utterance. Of course there is always a possibility that this negotiation does not go smoothly, in the sense that what the speaker originally intended is not received accordingly by the hearer. As a result, miscommunication and misunderstanding between the interlocutors may arise. Nevertheless, in a verbal interaction, such things may be easily rectified as the communication is done directly. Simply put, if

\footnotetext{
*Author(s) Correspondence:

E-mail: anugroho@bundamulia.ac.id
} 
the hearer misunderstands, he or she merely needs to clarify the actual meaning of the utterance directly to the speaker.

In writing, even though the negotiation of meaning is just as important as in a spoken conversation, it is more difficult since the reader and writer do not interact in a similar manner. Additionally, writers must not only try to convey their ideas through written discourse, but they must also consider their audience and interact with them indirectly. To this end, writers employ various linguistic tools to ensure that the intended message is delivered properly and accurately to the readers. One such device that is often used in writing is metadiscourse markers.

Metadiscourse can be generally defined as resources that writers use to organize and shape their arguments, which also reflect their stance towards both the content and readers (Hyland, 2004). It is an integral element of writing, especially in academic writing where the writers are expected to express their point of views and findings appropriately in accordance to existing academic norms. Several studies concerning this linguistic device have been conducted recently, such as the one by Khedri, Heng and Ebrahimi (2013) which investigated the use of interactive metadiscourse markers in research article abstracts from two disciplines, namely Applied Linguistics and Economics. Another study by Ozdemir and Longo (2014) explored how this linguistic device is utilized by American and Turkish writers in their thesis abstracts. Moreover, Kuhi and Mojood (2014) examined metadiscourse markers as well, but in editorial articles in newspapers written by Persian writers. Similarly, Sukma and Sujatna (2014) carried out a study on metadiscourse markers in opinion articles which were written by Indonesians. Lastly, Tavanpour, Goudarzi and Farnia (2016) compared the usage of interactive metadiscourse markers in sport news articles made by American and Iranian columnists.

The studies mentioned above are just a few out of numerous ones involving metadiscourse markers. Although some of them have enlightened us with how native speakers of English, i.e. Americans, and nonnatives, i.e. Turkish, Persian, Iranian, and Indonesian writers, employed these markers in their writing, little research has been done where Americans are directly compared with Indonesians. Furthermore, most of them have focused more on opinion, editorial, and sport articles, but not many have examined business ones. The reasoning behind selecting business articles as the object is that the previous studies have proven that different types of written discourse may lead to different usages of this linguistic device. This is in line with Hyland's (2005, as cited in Khedri, Heng and Ebrahimi, 2013) argument that the utilization of metadiscourse across disciplines is expected to be different as the nature of each varies between one another. Hence, it would be intriguing to explore whether this would also be true of this type of article as well. Considering this situation, the writer has become interested in investigating whether there are similarities and differences between how American and Indonesian writers incorporate metadiscourse markers in their opinion and business articles. From this, the following research questions are formulated:

1) What are the similarities and differences in the way American and Indonesian writers utilize metadiscourse markers in their opinion and business articles?

2) Which type of markers are most frequently found in the opinion and business articles?

The current study is limited to examining articles found in two online newspapers, namely Washington Examiner and The Jakarta Post. The corpus is also limited to approximately 7,000 words for each type of article. Furthermore, the articles are all dated between the last week of February and the first week of March 2020. The general topic of these articles revolves around coronavirus, stocks, and President Trump's impeachment.

\footnotetext{
*Author(s) Correspondence:

E-mail: anugroho@bundamulia.ac.id
} 


\section{LITERATURE REVIEW}

\section{Metadiscourse Markers}

According to Hyland (2005, as cited in Kuhi and Mojood, 2014), the term metadiscourse has been around since 1959 when it was first introduced by Zelling Hariss. It was originally understood as the way that writers or speakers try to guide the audience's perception of a particular text. The definition has since been further developed, e.g. it has been recognized as the linguistic tool that is not used to develop the content of a text, but rather used to help readers organize, interpret and evaluate them (Kopple, 1985; Crismore, Markkanen, and Steffensen, 1993, as cited in Sukma and Sujatna, 2014). It has also been generally seen as the author's way of organizing and limiting the expressive implications of a text (Schiffrin, 1980, as cited in Hyland and Tse, 2004). Furthermore, Hyland (2004, p. 134) defines metadiscourse as " ... the linguistic devices writers employ to shape their arguments to the needs and expectations of the target readers." Besides shaping writers' arguments, metadiscourse illustrates their stance towards the content or the readers (Hyland, 2005, as cited in Siddique, Mahmood and Iqbal, 2018). He goes on to say that this term can be considered as the umbrella term for various language features which helps readers organize and interpret the content of a text in the way that is intended by the writer. Thus, it can be concluded that metadiscourse deals with linguistic devices that writers employ in their writing to construct their arguments and limit the communicative consequences of what is being said, while at the same time reflecting the writers' stance towards either the content or the readers. This language feature also helps readers organize, interpret and evaluate what the writers have communicated in their preferred way.

Hyland (1999) classifies metadiscourse markers into two, namely textual and interpersonal. The first is concerned with the organization of information so that it becomes coherent and appropriate for a particular purpose. The latter deals with how writers express their point of view towards the content or the readers. It basically reflects their attitude, remoteness, and commitment to the proposition, as well as shows the degree of involvement of the reader. These two types are further categorized into more specific sub-groups such as logical connectives, frame markers and evidentials for the textual metadiscourse, and hedges, emphatics and attitude markers for the interpersonal metadiscourse. Nonetheless, the current study does not adopt Hyland's classification, but instead opts for the classification proposed by Dafouz-Milne (2008). This classification is selected as it provides a more accurate subdivision of categories that consider not only the linguistic device, but the pragmatic functions of the metadiscourse as well. In addition, it is also more suitable for newspaper articles, which are the object of this research. A summary of Dafouz-Milne's categorization of metadiscourse markers is presented below:

Table 1. Types of Textual Metadiscourse Markers (Dafouz-Milne, 2008)

\begin{tabular}{|c|c|c|}
\hline Macro-category & Subcategory & Examples \\
\hline \multirow{4}{*}{$\begin{array}{l}\text { Logical Markers: } \\
\text { Express semantic relationships } \\
\text { between discourse stretches }\end{array}$} & Additive & and / furthermore / in addition / moreover \\
\hline & Adversative & or / however / but \\
\hline & Consecutive & $\begin{array}{l}\text { so (as a result) / therefore / as a } \\
\text { consequence }\end{array}$ \\
\hline & Conclusive & finally / in any case \\
\hline $\begin{array}{l}\text { Sequencers: } \\
\text { Mark particular positions in a series }\end{array}$ & & $\begin{array}{l}\text { first / second / on the one hand, ... on the } \\
\text { other }\end{array}$ \\
\hline $\begin{array}{l}\text { Reminders: } \\
\text { Refer back to previous sections in the } \\
\text { text }\end{array}$ & & Let us return to / as was mentioned before \\
\hline
\end{tabular}

*Author(s) Correspondence:

E-mail: anugroho@bundamulia.ac.id 


\begin{tabular}{|c|c|c|}
\hline $\begin{array}{l}\text { Topicalisers: } \\
\text { Indicate topic shifts }\end{array}$ & & in political terms / in the case of the NHS \\
\hline \multirow{4}{*}{$\begin{array}{l}\text { Code Glosses: } \\
\text { Explain, rephrase or exemplify textual } \\
\text { material }\end{array}$} & Parentheses & When (as with the Tories now) \\
\hline & Punctuation devices & $\begin{array}{l}\text { Tax evasion: it is deplored on others but not } \\
\text { in oneself }\end{array}$ \\
\hline & Reformulators & in other words / that is / to put it simply \\
\hline & Exemplifiers & for example / for instance \\
\hline $\begin{array}{l}\text { Illocutionary Markers: } \\
\text { Explicitly name the act the writer } \\
\text { performs }\end{array}$ & & I propose / I hope to persuade \\
\hline $\begin{array}{l}\text { Announcements: } \\
\text { Refer forwards to future sections in the } \\
\text { text }\end{array}$ & & $\begin{array}{l}\text { there are many good reasons / as we'll see } \\
\text { later }\end{array}$ \\
\hline
\end{tabular}

Table 2. Types of Interpersonal Metadiscourse Markers (Dafouz-Milne, 2008)

\begin{tabular}{|l|l|l|}
\hline \multicolumn{1}{|c|}{ Macro-category } & \multicolumn{1}{|c|}{ Subcategory } & \multicolumn{1}{c|}{ Examples } \\
\hline \multirow{2}{*}{$\begin{array}{l}\text { Hedges: } \\
\text { Express partial commitment to the } \\
\text { truth-value of the text }\end{array}$} & Epistemic verbs & May / might / it must be two o'clock \\
\cline { 2 - 3 } $\begin{array}{l}\text { Certainty markers: } \\
\text { Express total commitment to the truth- } \\
\text { value of the text }\end{array}$ & Probability adverbs & Probably / perhaps / maybe \\
\cline { 2 - 3 } $\begin{array}{l}\text { Attributors: } \\
\text { Refer to the source of information }\end{array}$ & Epistemic expressions & It is likely \\
\hline \multirow{3}{*}{$\begin{array}{l}\text { Attitude markers: } \\
\text { Express writers' affective values } \\
\text { towards text and readers }\end{array}$} & Undoubtedly / clearly / certainly \\
\hline \multirow{4}{*}{$\begin{array}{l}\text { Commentaries: } \\
\text { Help to establish reader-writer rapport } \\
\text { through the text }\end{array}$} & Deontic verbs & $\begin{array}{l}\text { 'x' claims that. . / As the Prime Minister } \\
\text { remarked }\end{array}$ \\
\cline { 2 - 3 } & Attitudinal adverbs & Have to / we must understand / needs to \\
\cline { 2 - 3 } & Attitudinal adjectives & Unfortunately / remarkably / pathetically \\
\cline { 2 - 3 } & Cognitive verbs & I feel / I think / I believe \\
\cline { 2 - 3 } & Rhetorical questions & $\begin{array}{l}\text { What is the future of Europe, integration or } \\
\text { disintegration? }\end{array}$ \\
\cline { 2 - 3 } & Pirect address to reader & You must understand, dear reader \\
\cline { 2 - 3 } & Personalisations & We all believe / let us summarise \\
\hline
\end{tabular}

\section{RESEARCH METHODOLOGY}

\section{Data Source}

The data for this research is taken from articles from two online newspapers, i.e. Washington Examiner and The Jakarta Post. The first is a newspaper written by native speakers of English, specifically Americans, whereas the other is written by nonnative speakers, Indonesians to be precise. The reason why the writer decided to take the articles from these two online newspapers is related to convenience. First of all, Washington Examiner is selected since it is readily available online for free. Other major newspapers such as The New York Times or The Washington Post are not completely free. In other words, in order to be able to read more than one article, one must subscribe to it beforehand. As for the Washington Examiner, it is still free and people are able to read all of the articles without having to subscribe. Lastly, the writer chose The Jakarta Post not only for the same reason as the first one, but because it is also one of the most popular online newspapers in English which is written by Indonesians.

*Author(s) Correspondence:

E-mail: anugroho@bundamulia.ac.id 
The number of articles taken from these two online newspapers is not specifically determined since the size varies between each of them. What is determined is the size of the corpus, which is approximately 7,000 words for each type of article. As there are two types of newspaper articles, namely opinion and business articles, and two groups of writers which are observed, the total size of the corpus is around 28,000 words. It should be noted that overall, opinion articles are longer in length compared to business articles, and the articles written by Indonesians are also longer than the ones written by Americans. Which means that more business articles were taken to fulfill the 7,000 words target compared to opinion articles, and as a whole, more articles written by Americans were collected in comparison to Indonesian articles. Last but not least, the writer took articles which are dated around the end of February and early March 2020. The topic of the articles varies, but in general they are mostly about coronavirus, stocks, and President Trump's impeachment.

\section{Data Collection and Analysis Procedures}

To collect the data, the writer first searched for the online newspapers that could be used as the source of data. After determining the newspapers, opinion and business articles dated around the end of February and early March 2020 were collected and saved. The number of articles was not specified, but the writer stopped collecting the articles after reaching approximately 7.000 words for each type. Finally, the articles were converted into text format, so that they could be inputted into the software that is used to analyze the data.

As for the data analysis procedure, the articles which have been collected and converted into text format were inputted into the software, namely the AntConc software version 3.5.6 by Anthony (2018). Afterwards, the writer used said software to generate the word list for each type of article from each group. From this word list, the metadiscourse markers are analyzed based on the classification from Dafouz-Milne (2008). The analysis involves checking the concordance lines in which these words appear to ensure that they truly function as metadiscourse markers. The frequency of the markers are then summarized and compared between opinion and business articles from both online newspapers to see whether there are any similarities and differences in the way native and nonnative speakers of English employ this linguistic device in their writing. Lastly, conclusions and suggestions are made based on the findings of the current research.

\section{FINDINGS AND DISCUSSIONS}

To find out whether Americans and Indonesians utilize metadiscourse markers in a similar or different manner in their writing, several articles from Washington Examiner and The Jakarta Post have been collected and analyzed. To begin with, let us take a closer look at the articles written by the native speakers. Referring to Dafouz-Milne's (2008) categorization, metadiscourse is divided into textual and interpersonal, and both of these are further classified into more specific macrocategories and subcategories. A brief summary of the frequency of the textual metadiscourse markers found in the Washington Examiner is presented below:

\footnotetext{
*Author(s) Correspondence:

E-mail: anugroho@bundamulia.ac.id
} 
Table 3. Textual Metadiscourse Markers in Washington Examiner

\begin{tabular}{|c|c|c|c|c|c|c|c|c|c|}
\hline \multicolumn{5}{|c|}{ Opinion Articles } & \multicolumn{5}{|c|}{ Business Articles } \\
\hline \multicolumn{3}{|c|}{ Textual Metadiscourse Marker } & \multicolumn{2}{|c|}{ Total } & \multicolumn{3}{|c|}{ Textual Metadiscourse Marker } & \multicolumn{2}{|c|}{ Total } \\
\hline \multirow{9}{*}{$\begin{array}{c}\text { Logical } \\
\text { Markers }\end{array}$} & \multirow{3}{*}{ Additive } & and & 177 & \multirow{9}{*}{257} & \multirow{9}{*}{ Logical Markers } & \multirow{3}{*}{ Additive } & and & 159 & \multirow{9}{*}{188} \\
\hline & & \multirow{2}{*}{ furthermore } & \multirow{2}{*}{1} & & & & furthermore & 1 & \\
\hline & & & & & & & in addition & 1 & \\
\hline & \multirow{3}{*}{ Adversative } & or & 34 & & & \multirow{3}{*}{ Adversative } & or & 10 & \\
\hline & & \multirow{2}{*}{ but } & \multirow{2}{*}{34} & & & & however & 1 & \\
\hline & & & & & & & but & 12 & \\
\hline & \multirow{2}{*}{ Consecutive } & so & 10 & & & \multirow{2}{*}{ Consecutive } & so & 3 & \\
\hline & & as a result & 1 & & & & as a result & 1 & \\
\hline & Conclusive & - & - & & & Conclusive & - & - & \\
\hline \multirow{2}{*}{\multicolumn{2}{|c|}{ Sequencers }} & first & 1 & & \multirow{2}{*}{\multicolumn{2}{|c|}{ Sequencers }} & - & - & \\
\hline & & second & 1 & 2 & & & - & - & - \\
\hline \multicolumn{2}{|c|}{ Reminders } & - & - & - & \multicolumn{2}{|c|}{ Reminders } & - & - & - \\
\hline \multicolumn{2}{|c|}{ Topicalisers } & in terms of & 1 & 1 & \multicolumn{2}{|c|}{ Topicalisers } & - & - & - \\
\hline \multirow{3}{*}{ Code Glosses } & Reformulators & that is & 1 & \multirow{3}{*}{7} & \multirow{3}{*}{ Code Glosses } & Reformulators & - & - & \\
\hline & & for instance & 1 & & & \multirow{2}{*}{ Exemplifiers } & for example & 2 & 11 \\
\hline & Exemplifiers & such as & 5 & & & & such as & 9 & \\
\hline \multicolumn{2}{|c|}{ Illocutionary Markers } & - & - & - & \multicolumn{2}{|c|}{ Illocutionary Markers } & - & - & - \\
\hline \multicolumn{2}{|c|}{ Announcements } & - & - & - & \multicolumn{2}{|c|}{ Announcements } & - & - & - \\
\hline & Total & & & 267 & & Total & & & 199 \\
\hline
\end{tabular}

At a glance, the findings reveal that more of these markers are found in opinion articles compared to business ones, with a total of $\mathbf{2 6 7}$ words for the first group and $\mathbf{1 9 9}$ for the other. Overall, the most dominant type for both articles is logical markers, where 257 and $\mathbf{1 8 8}$ of these are found in the opinion and business articles respectively. From these totals, the word that is mostly used by the writers is the conjunction and. Moreover, it can be seen that even though logical markers are classified into 4 subcategories, i.e. additive, adversative, consecutive, and conclusive, no words from the last group can be found in both opinion and business articles. Similarly, from the 7 macro-categories of textual metadiscourse markers, 3 of them also do not appear at all in both types of articles, namely reminders, illocutionary markers and announcements. It should also be noted that for the code glosses category, parentheses and punctuation devices are not included in the data collection and analysis as the focus of this study is more towards 'words' and not 'symbols.' Finally, some example concordance lines which illustrate the usage of textual metadiscourse markers can be seen below:
... only the second impeachment in history, and it was being done more than a century ...

$>$... a prayer of removing him from office, but they also knew impeachment might have ...

$>$... grandmother in Sumter, told me. Second, the experience provides a steadying ...

$>$... At some venues, such as the NMSU Pan American Center in New Mexico, a standing ...

If we compare the findings for both types of articles, we can see that in general there are some similarities and differences in the usage of textual metadiscourse markers. Firstly, they are somewhat similar in the words that are used. That is, the writers employed more or less similar words for both opinion and business articles such as and, furthermore, or, but, as a result, and such as. Even their frequencies are not too different, with and being the most frequent, and words like furthermore and as a result only appearing once in both groups of articles. In addition, even when some words appear in one group

*Author(s) Correspondence:

E-mail: anugroho@bundamulia.ac.id 
but not in the other, the frequency is also not too different. For instance, two sequencers appear in opinion articles but not in the business ones. As for the differences, the rather obvious ones concern the frequency of certain words. To put it another way, the words used are similar, but their frequency differs quite a lot. For example, the conjunction and is found $\mathbf{1 7 7}$ times in opinion articles and 159 times in business articles, so the difference in frequency is 18. Likewise, the words or and but are found around three times as frequently in opinion articles compared to the other group.

Table 4. Interpersonal Metadiscourse Markers in Washington Examiner

\begin{tabular}{|c|c|c|c|c|c|c|c|c|c|}
\hline \multicolumn{5}{|c|}{ Opinion Articles } & \multicolumn{5}{|c|}{ Business Articles } \\
\hline \multicolumn{3}{|c|}{ Interpersonal Metadiscourse Marker } & \multicolumn{2}{|c|}{ Total } & \multicolumn{3}{|c|}{ Interpersonal Metadiscourse Marker } & \multicolumn{2}{|c|}{ Total } \\
\hline \multirow{5}{*}{ Hedges } & Epistemic & may & 1 & \multirow{5}{*}{17} & & \multirow{2}{*}{$\begin{array}{c}\text { Epistemic } \\
\text { Verbs }\end{array}$} & may & 3 & \multirow{5}{*}{7} \\
\hline & Verbs & might & 5 & & & & might & 2 & \\
\hline & Probability & perhaps & 5 & & Hedges & Probability & - & - & \\
\hline & Adverbs & maybe & 1 & & Heages & Adverbs & - & - & \\
\hline & $\begin{array}{c}\text { Epistemic } \\
\text { Expressions }\end{array}$ & likely & 5 & & & $\begin{array}{c}\text { Epistemic } \\
\text { Expressions }\end{array}$ & likely & 2 & \\
\hline \multicolumn{2}{|c|}{ Certainty Markers } & - & - & - & \multicolumn{2}{|c|}{ Certainty Markers } & - & - & - \\
\hline \multirow{2}{*}{\multicolumn{2}{|c|}{ Attributors }} & \multirow{2}{*}{ said } & \multirow{2}{*}{37} & \multirow{2}{*}{37} & \multirow{2}{*}{\multicolumn{2}{|c|}{ Attributors }} & said & 65 & 68 \\
\hline & & & & & & & stated & 3 & \\
\hline \multirow{5}{*}{$\begin{array}{l}\text { Attitude } \\
\text { Markers }\end{array}$} & \multirow{2}{*}{ Deontic Verbs } & must & 1 & \multirow{5}{*}{2} & \multirow{5}{*}{$\begin{array}{l}\text { Attitude } \\
\text { Markers }\end{array}$} & \multirow{2}{*}{ Deontic Verbs } & must & 1 & \multirow{5}{*}{1} \\
\hline & & have to & 1 & & & & - & - & \\
\hline & $\begin{array}{l}\text { Attitudinal } \\
\text { Adverbs }\end{array}$ & - & - & & & $\begin{array}{l}\text { Attitudinal } \\
\text { Adverbs }\end{array}$ & - & - & \\
\hline & $\begin{array}{l}\text { Attitudinal } \\
\text { Adjectives }\end{array}$ & - & - & & & $\begin{array}{l}\text { Attitudinal } \\
\text { Adjectives }\end{array}$ & - & - & \\
\hline & $\begin{array}{l}\text { Cognitive } \\
\text { Adverbs }\end{array}$ & - & - & & & $\begin{array}{l}\text { Cognitive } \\
\text { Adverbs }\end{array}$ & - & - & \\
\hline \multirow{7}{*}{$\begin{array}{l}\text { Commen- } \\
\text { taries }\end{array}$} & $\begin{array}{l}\text { Rhetorical } \\
\text { Questions }\end{array}$ & what ... & 2 & \multirow{7}{*}{17} & \multirow{7}{*}{$\begin{array}{c}\text { Commen- } \\
\text { taries }\end{array}$} & $\begin{array}{l}\text { Rhetorical } \\
\text { Questions }\end{array}$ & - & - & \\
\hline & $\begin{array}{c}\text { Direct } \\
\text { Address to } \\
\text { Reader }\end{array}$ & you & 7 & & & $\begin{array}{c}\text { Direct } \\
\text { Address to } \\
\text { Reader }\end{array}$ & - & - & \\
\hline & \multirow{2}{*}{$\begin{array}{c}\text { Inclusive } \\
\text { Expressions }\end{array}$} & we & 4 & & & Inclusive & & & - \\
\hline & & us & 2 & & & Expressions & - & - & \\
\hline & \multirow{2}{*}{$\begin{array}{c}\text { Personalisa- } \\
\text { tions }\end{array}$} & me & 1 & & & \multirow{2}{*}{$\begin{array}{l}\text { Personalisa- } \\
\text { tions }\end{array}$} & \multirow[b]{2}{*}{ - } & \multirow{2}{*}{ - } & \\
\hline & & $\mathrm{I}$ & 1 & & & & & & \\
\hline & Asides & - & - & & & Asides & - & - & \\
\hline \multicolumn{4}{|c|}{ Total } & 73 & & Total & & & 76 \\
\hline
\end{tabular}

After reviewing the result of the first type of metadiscourse marker, let us now look at the second type, namely the interpersonal marker. It can be seen from Table $\mathbf{4}$ above that the total for both groups of articles are very similar, i.e. $\mathbf{7 3}$ for opinion and $\mathbf{7 6}$ for business articles. In addition, no certainty markers are found in either articles, and the usage of attitude markers are very much alike in both. However, if we take a closer look, there are also some noticeable differences. For starters, more hedges are used in the first group compared to the other one. There are 5 words found in the opinion articles that fall under this macro-category (i.e. may, might, perhaps, maybe and likely) with a total frequency of $\mathbf{1 7}$, and only 3 words for the business articles (i.e. may, might and likely) with only a total of 7 occurrences. In contrast, more attributors are found in the second group in comparison to the first, with 68 occurrences in the business articles and only $\mathbf{3 7}$ in the opinion articles.

*Author(s) Correspondence:

E-mail: anugroho@bundamulia.ac.id 
There is only one word, i.e. said found in the first group, but two words, i.e. said and stated found in the other. Finally, in terms of commentaries, it is found that this type of marker appeared $\mathbf{1 7}$ times in the opinion articles, but not once in the business articles.

Looking at these results, there are several discussions that can be made. Firstly, it is likely that more hedges are found in opinion articles since the writing is more about the writers' personal point of views. When expressing their opinions, they may not be entirely certain of their statements, or they may want to reduce the 'impact' of their claims, which leads them to using hedges. On the other hand, writers of business articles probably do not need to employ as many hedges as they mostly report on facts related to economy and business. Next, a lot more attributors can be found in business articles as opposed to the other group, most likely because the writers quote a lot of statements from other people; whereas in opinion articles, the writers would need to do this less as they are mostly describing their own thoughts. Furthermore, it is probable that writers of the first group include numerous commentaries in their writing due to the nature of opinion articles which try to involve the readers more.
It is also important to show whose opinion is being discussed, hence the usage of personalisations like $m e$ and $I$. These of course are not really necessary for business articles since the news that are being reported are not about people's opinions but more about specific facts and situations. Lastly, to demonstrate how these markers are used in the articles, some concordance lines are presented below:

... fears that the coronavirus may spread across the U.S. and to other countries have ...

... particularly since the 2007-2009 recession," Gallup stated in the poll's press release ...

$>\ldots$ act as if it were a painful necessity, not something you are doing for fun or out of ...

Moving on, we shall now take a closer look at the metadiscourse markers produced by Indonesian writers. The first type to be observed is the textual metadiscourse, and the findings are summarized in the following table:

Table 5. Textual Metadiscourse Markers in The Jakarta Post

\begin{tabular}{|c|c|c|c|c|c|c|c|c|c|}
\hline \multicolumn{5}{|c|}{ Opinion Articles } & \multicolumn{5}{|c|}{ Business Articles } \\
\hline \multicolumn{3}{|c|}{ Textual Metadiscourse Marker } & \multicolumn{2}{|c|}{ Total } & \multicolumn{3}{|c|}{ Textual Metadiscourse Marker } & \multicolumn{2}{|c|}{ Total } \\
\hline \multirow{11}{*}{$\begin{array}{c}\text { Logical } \\
\text { Markers }\end{array}$} & \multirow{4}{*}{ Additive } & and & 189 & \multirow{11}{*}{265} & \multirow{11}{*}{ Logical Markers } & \multirow{4}{*}{ Additive } & \multirow{2}{*}{ and } & \multirow{2}{*}{164} & \\
\hline & & furthermore & 1 & & & & & & \\
\hline & & in addition & 1 & & & & \multirow{2}{*}{ in addition } & \multirow{2}{*}{1} & \multirow{9}{*}{196} \\
\hline & & moreover & 1 & & & & & & \\
\hline & \multirow{3}{*}{ Adversative } & or & 26 & & & \multirow{6}{*}{ Consecutive } & or & 9 & \\
\hline & & however & 13 & & & & however & 5 & \\
\hline & & but & 25 & & & & but & 10 & \\
\hline & \multirow{3}{*}{ Consecutive } & so & 3 & & & & & 6 & \\
\hline & & as a result & 3 & & & & so & 6 & \\
\hline & & therefore & 3 & & & & therefore & 1 & \\
\hline & Conclusive & - & - & & & Conclusive & - & - & \\
\hline & & firct & 2 & & & & first & 1 & \\
\hline & & TIISSt & 2 & & & & second & 1 & \\
\hline & & & & & & & third & 1 & \\
\hline & cers & second & 2 & 6 & Seque & ers & fourth & 1 & 6 \\
\hline & & & & & & & fifth & 1 & \\
\hline & & third & 2 & & & & $\begin{array}{c}\text { on the other } \\
\text { hand }\end{array}$ & 1 & \\
\hline & lers & - & - & - & Remi & & - & - & - \\
\hline
\end{tabular}

*Author(s) Correspondence:

E-mail: anugroho@bundamulia.ac.id 


\begin{tabular}{|c|c|c|c|c|c|c|c|c|c|}
\hline \multicolumn{2}{|c|}{ Topicalisers } & - & - & - & \multicolumn{2}{|c|}{ Topicalisers } & $\begin{array}{c}\text { in the case } \\
\text { of }\end{array}$ & 1 & 1 \\
\hline \multirow{3}{*}{ Code Glosses } & Reformulators & - & - & \multirow{3}{*}{11} & \multirow{3}{*}{ Code Glosses } & Reformulators & - & - & \multirow{3}{*}{5} \\
\hline & \multirow{2}{*}{ Exemplifiers } & for example & 4 & & & \multirow{2}{*}{ Exemplifiers } & for instance & 1 & \\
\hline & & $\begin{array}{c}\text { for instance } \\
\text { such as }\end{array}$ & $\frac{2}{5}$ & & & & such as & 4 & \\
\hline \multicolumn{2}{|c|}{ Illocutionary Markers } & - & - & - & \multicolumn{2}{|c|}{ Illocutionary Markers } & - & - & - \\
\hline \multicolumn{2}{|c|}{ Announcements } & - & - & - & \multicolumn{2}{|c|}{ Announcements } & - & - & - \\
\hline \multicolumn{4}{|c|}{ Total } & 282 & \multicolumn{4}{|c|}{ Total } & 208 \\
\hline
\end{tabular}

The results shown in Table 5 above depict some similarities and differences in the way Indonesian utilize these markers in their writing of opinion and business articles. Starting with the similarities, the most dominant type of marker found in both articles is the logical markers. This is most likely due to the fact that these words are very common words that can be found in any kind of writing as they are essential in showing the connection between sentences. Next, both of them have the same number of sequencers, i.e. 6. Of course, it should be noted that the second group have more words included in this type in comparison to the first group. To be more precise, the first only has 3 words, namely first, second and third, with each occurring twice, whereas the latter has 6 words (i.e. first, second, third, fourth, fifth and on the other hand), but each appearing only once. Lastly, no reminders, illocutionary markers and announcements are present in both opinion and business articles.

Besides the similarities, there are also some differences. First of all, although logical markers are the most frequently found marker in both groups, their frequency is quite different, with the opinion articles having more of them, that is, as many as $\mathbf{2 6 5}$ occurrences, and only 196 in the business ones. This might be because the sentences in the first group are more 'varied' in the sense that many different ideas and arguments of the writers are presented in this kind of discourse. On the other hand, the latter group may not have as many ideas and arguments since the topic is more specific, namely talking about economy and business. Moreover, there are more words that fall under this category in the first group compared to the other, namely 10 words (and, furthermore, in addition, moreover, or, however, but, so, as a result and therefore) and 7 words (and, in addition, or, however, but, so and therefore). In addition, there is one instance of a topicaliser used in business articles, but none in opinion articles. Finally, there are less code glosses in the second group compared to the first (i.e. only $\mathbf{5}$ in business articles, but $\mathbf{1 1}$ in opinion ones). Although the difference is not too significant, it is probable that more of this type of marker is found in opinion articles since the writers need to make their opinions clearer by providing examples. In contrast, writers of business articles may not need to give too many examples as their statements are mostly based on facts. Some example concordance lines are shown below to illustrate how these words are used in the articles:

$>\quad \ldots 1.20$ million recorded in the same month in 2019. However, the growth is much lower...

$>\ldots$ increased the volume [of intervention] so the market is assured and confident that ...

$>$... interest are popular Asian models, such as Hyundai's Palisade and Subaru Corp's...

The next type of marker that is going to be examined is the interpersonal metadiscourse marker that the Indonesian writers utilized in their writing of opinion and business articles. The following table is a summary of the findings for this marker:

*Author(s) Correspondence:

E-mail: anugroho@bundamulia.ac.id 
Table 6. Interpersonal Metadiscourse Markers in The Jakarta Post

\begin{tabular}{|c|c|c|c|c|c|c|c|c|c|}
\hline \multicolumn{5}{|c|}{ Opinion Articles } & \multicolumn{5}{|c|}{ Business Articles } \\
\hline \multicolumn{3}{|c|}{ Interpersonal Metadiscourse Marker } & \multicolumn{2}{|c|}{ Total } & \multicolumn{3}{|c|}{ Interpersonal Metadiscourse Marker } & \multicolumn{2}{|c|}{ Total } \\
\hline \multirow{4}{*}{ Hedges } & Epistemic & may & 16 & \multirow{4}{*}{28} & \multirow{4}{*}{ Hedges } & \multirow{2}{*}{$\begin{array}{c}\text { Epistemic } \\
\text { Verbs }\end{array}$} & may & 5 & \multirow{4}{*}{7} \\
\hline & Verbs & might & 2 & & & & might & 2 & \\
\hline & $\begin{array}{c}\text { Probability } \\
\text { Adverbs }\end{array}$ & perhaps & 3 & & & $\begin{array}{c}\text { Probability } \\
\text { Adverbs }\end{array}$ & - & - & \\
\hline & $\begin{array}{c}\text { Epistemic } \\
\text { Expressions }\end{array}$ & likely & 7 & & & $\begin{array}{c}\text { Epistemic } \\
\text { Expressions }\end{array}$ & - & - & \\
\hline \multicolumn{2}{|c|}{ Certainty Markers } & - & - & - & \multicolumn{2}{|c|}{ Certainty Markers } & - & - & - \\
\hline \multirow{2}{*}{\multicolumn{2}{|c|}{ Attributors }} & \multirow{2}{*}{ said } & \multirow{2}{*}{2} & \multirow{2}{*}{2} & \multirow{2}{*}{\multicolumn{2}{|c|}{ Attributors }} & said & 71 & \\
\hline & & & & & & & stated & 1 & 72 \\
\hline \multirow{5}{*}{$\begin{array}{l}\text { Attitude } \\
\text { Markers }\end{array}$} & \multirow{2}{*}{ Deontic Verbs } & must & 14 & \multirow{5}{*}{20} & \multirow{5}{*}{$\begin{array}{l}\text { Attitude } \\
\text { Markers }\end{array}$} & \multirow{2}{*}{ Deontic Verbs } & must & 1 & \multirow{5}{*}{2} \\
\hline & & need to & 6 & & & & need to & 1 & \\
\hline & $\begin{array}{l}\text { Attitudinal } \\
\text { Adverbs }\end{array}$ & - & - & & & $\begin{array}{l}\text { Attitudinal } \\
\text { Adverbs }\end{array}$ & - & - & \\
\hline & $\begin{array}{l}\text { Attitudinal } \\
\text { Adjectives }\end{array}$ & - & - & & & $\begin{array}{c}\text { Attitudinal } \\
\text { Adjectives }\end{array}$ & - & - & \\
\hline & $\begin{array}{l}\text { Cognitive } \\
\text { Adverbs }\end{array}$ & - & - & & & $\begin{array}{l}\text { Cognitive } \\
\text { Adverbs }\end{array}$ & - & - & \\
\hline \multirow{7}{*}{$\begin{array}{c}\text { Commen- } \\
\text { taries }\end{array}$} & $\begin{array}{l}\text { Rhetorical } \\
\text { Questions }\end{array}$ & - & - & \multirow{7}{*}{34} & \multirow{7}{*}{$\begin{array}{l}\text { Commen- } \\
\text { taries }\end{array}$} & $\begin{array}{c}\text { Rhetorical } \\
\text { Questions }\end{array}$ & - & - & \\
\hline & $\begin{array}{c}\text { Direct } \\
\text { Address to } \\
\text { Reader }\end{array}$ & you & 3 & & & $\begin{array}{c}\text { Direct } \\
\text { Address to } \\
\text { Reader }\end{array}$ & - & - & \\
\hline & \multirow{2}{*}{$\begin{array}{c}\text { Inclusive } \\
\text { Expressions }\end{array}$} & we & 25 & & & Inclusive & - & & - \\
\hline & & us & 2 & & & Expressions & - & - & \\
\hline & \multirow{3}{*}{$\begin{array}{c}\begin{array}{c}\text { Personalisa- } \\
\text { tions }\end{array} \\
\text { Asides }\end{array}$} & me & 1 & & & \multirow{2}{*}{$\begin{array}{c}\text { Personalisa- } \\
\text { tions }\end{array}$} & - & - & \\
\hline & & $\mathrm{I}$ & 3 & & & & - & - & \\
\hline & & - & - & & & Asides & - & - & \\
\hline \multicolumn{4}{|c|}{ Total } & 84 & & Total & & & 81 \\
\hline
\end{tabular}

Some similarities and differences can be observed from Table 6 above. First of all, in terms of the similarities, the overall total between the markers found in opinion and business articles are more or less similar, that is 84 in opinion and 81 in business articles. The last similarity is that no certainty markers can be found in either group of articles. This goes to show that Indonesian writers may not prefer to express their certainty towards their ideas in the opinion articles, which is perhaps influenced by the Indonesian culture where in general people tend to be less direct. They may also feel that they do not need to use these kinds of markers in business articles as most of the data presented in them are based on statistics and actual facts, so it would not be necessary to explicitly show their certainty for these kinds of statements.

*Author(s) Correspondence:

E-mail: anugroho@bundamulia.ac.id
As for the differences, it is found that there are quite a few between the markers used in the two groups of articles. The first difference is in the number of hedges used. It can be seen that there are four times as many of them in opinion articles compared to business ones, i.e. $\mathbf{2 8}$ and $\mathbf{7}$ respectively. It is likely that more of this of type of marker is used by opinion article writers because they feel that they need to lessen the impact of their arguments using hedges; whereas for the writers of business articles, since most of the statements are not really their own ideas, they may think that it is not too necessary to employ them. The next difference concerns attributors, where a lot more of them are utilized in business articles. There are $\mathbf{7 2}$ occurrences of this marker found in business articles, and only $\mathbf{2}$ of them in opinion articles. This is perhaps because words such as said are 
not really required in opinion articles as the statements are mostly from the writers themselves. Different with business articles, where accounts from various people are quoted, words like said and stated are indeed important. Besides hedges and attributors, the attitude markers for both groups of articles are also quite different in terms of frequency. As many as 20 are used by opinion writers, but only 2 are employed by the writers of the other group. A probable reason for this is that writers of the first group may express a lot of their own point of views and opinions; hence, they are more likely to use words such as must and need to. On the contrary, the writers of the other group may not use this as frequently as they are mostly reporting on facts and other business related news. Finally, it can be seen that many commentaries are found in opinion articles, but none in business ones. The most frequent word that fall under this type is the inclusive expression we, with $\mathbf{2 5}$ occurrences out of a total of $\mathbf{3 4}$. This goes to show that the writers try to involve the readers in their discourse by employing this word and perhaps even try to position themselves in the same group as them. The following sentences are examples of how these words are used in the articles:

$\ldots$ is therefore highly likely that some Indonesians contracted the virus but went undetected ...

$>$... steps and improvement must be done to overcome these collective challenges ... ... democracy as permissible, at least we now know that for most would-be autocrats ...

Now that we have examined how these markers are utilized by American and Indonesian writers in both opinion and business articles, we are going to take a look at the summary of these comparisons presented in Table 7 below.

Table 7. Summary of Metadiscourse Markers Found in Both Online Newspapers

\begin{tabular}{|c|c|c|c|c|c|}
\hline & \multicolumn{2}{|c|}{ Washington Examiner } & \multicolumn{2}{|c|}{ The Jakarta Post } \\
\hline & & Opinion Articles & Business Articles & Opinion Articles & Business Articles \\
\hline \multirow{7}{*}{$\begin{array}{c}\text { Textual } \\
\text { Metadiscourse } \\
\text { Marker }\end{array}$} & Logical Markers & 257 & 188 & 265 & 196 \\
\hline & Sequencers & 2 & - & 6 & 6 \\
\hline & Reminders & - & - & - & - \\
\hline & Topicalisers & 1 & - & - & 1 \\
\hline & Code Glosses & 7 & 11 & 11 & 5 \\
\hline & $\begin{array}{c}\text { Illocutionary } \\
\text { Markers }\end{array}$ & - & - & - & - \\
\hline & Announcements & - & - & - & - \\
\hline \multirow{5}{*}{$\begin{array}{l}\text { Interpersonal } \\
\text { Metadiscourse } \\
\text { Marker }\end{array}$} & Hedges & 17 & 7 & 28 & 7 \\
\hline & $\begin{array}{l}\text { Certainty } \\
\text { Markers }\end{array}$ & - & - & - & - \\
\hline & Attributors & 37 & 68 & 2 & 72 \\
\hline & $\begin{array}{l}\text { Attitude } \\
\text { Markers }\end{array}$ & 2 & 1 & 20 & 2 \\
\hline & Commentaries & 17 & - & 34 & - \\
\hline \multicolumn{2}{|c|}{ Total } & 340 & 275 & 366 & 289 \\
\hline
\end{tabular}

The summary reveals that as a whole, there are some obvious similarities and differences between how textual and interpersonal markers are employed in opinion and business articles written by Americans and Indonesians. For example, more logical markers can be found in opinion compared to business articles in both online newspapers. Both groups of writers also used attributors more frequently in business articles than in opinion ones. Another apparent similarity is the fact that in total, opinion articles have more textual and

*Author(s) Correspondence:

E-mail: anugroho@bundamulia.ac.id 
interpersonal markers in comparison to business articles in both newspapers. On the other hand, some clear differences between the two newspapers can also be identified, such as the use of sequencers in business articles in The Jakarta Post, but none such usage in those from Washington Examiner. Code glosses are also more common in the business articles in Washington Examiner, but they can be found more frequently in the opinion articles of the other newspaper. Another difference worth noting deals with the frequency of attitude markers and commentaries found in the opinion articles in The Jakarta Post. To be precise, a lot more of these markers are used by Indonesian writers as opposed to Americans.

Based on the findings mentioned above, there are two main points worth discussing. First of all, it is found that opinion and business articles are indeed quite different in terms of the metadiscourse markers employed in each group. For instance, writers of opinion articles tend to incorporate more textual and interpersonal markers compared to writers of business articles. This is somewhat in line with Hyland's claim that the usage of these markers will vary across disciplines. Although not exactly two different kinds of disciplines, these two types of articles do have some specific norms regarding metadiscourse use and it is clearly reflected in the way these markers are utilized in each group of articles. The last discussion involves the similarities and differences between the American and Indonesian writers. In general, it can be seen that they both share some similarities and some differences in their utilization of this linguistic device. One example similarity is that both groups of people did not use any reminders, illocutionary markers, announcements, and certainty markers anywhere in their opinion or business articles. On the other hand, some differences include the frequency of certain markers like attributors, attitude markers and commentaries which are quite different between both groups. This indicates that culture influences the way writers use metadiscourse markers to some extent. For example, it is probable that Indonesian writers used twice as many commentaries as Americans because collectivism is more important in eastern cultures as opposed to western where individualism is more dominant. Therefore, it can be said that the background of the writers may affect the way they use metadiscourse markers in their writing.

\section{CONCLUSION AND SUGGESTIONS}

Referring to the findings and discussion described in the previous section, and in order to answer the main research questions of the current study, the writer has drawn two general conclusions. First of all, American and Indonesian writers employ metadiscourse markers both similarly and differently in their writing of opinion and business articles. The similarities include things such as the absence of certain types of markers like reminders and announcements in both groups of articles, whereas the differences involve things such as the frequency of certain markers, where one group of people would use much more of one type in opinion articles, and the other group would use a different type more often in business ones. From this, it can be concluded that both the type of discourse and the cultural background of the writers influence the utilization of these markers. The final conclusion deals with the most frequent type of marker found in each type of article. Overall, more markers can be found in opinion articles compared to business articles, be it in Washington Examiner and The Jakarta Post. Moreover, between textual and interpersonal markers, the more dominant one is the former. More specifically, logical markers are the most frequently occurring marker in both opinion and business articles since this type include very common words like and, or and but. Thus, it can be concluded that textual metadiscourse markers are an integral part of newspaper discourse as various information is presented, and it is imperative that these markers are employed in order to make the text more comprehensible.

*Author(s) Correspondence:

E-mail: anugroho@bundamulia.ac.id 
Last but not least, the writer realizes that this research is limited in numerous aspects, such as the limitation on the size of the corpus and the type of articles that are examined. Hence, the writer would like to suggest that future studies on the topic of metadiscourse would include a larger sized corpus and other types of articles such as editorials, sport articles, etc. Moreover, this study only compared between American and Indonesian writers. It would be interesting to investigate and compare between people from other different cultural backgrounds as well.

\section{REFERENCES}

Anthony, L. (2018). AntConc (Version 3.5.6) [Computer Software]. Tokyo, Japan: Waseda University. Available from http://www.laurenceanthony.net/softw are

Dafouz-Milne, E. (2008). The pragmatic role of textual and interpersonal metadiscourse markers in the construction and attainment of persuasion: A cross-linguistic study of newspaper discourse. Journal of Pragmatics, 40, (1), 95 - 113.

Hyland, K. (1999). Talking to students: metadiscourse in introductory coursebooks. English for Specific Purposes 18, (1), 3 - 26.

Hyland, K. (2004). Disciplinary interactions: metadiscourse in L2 postgraduate writing. Journal of Second Language Writing, 13, 133 - 151.

Hyland, K. and Tse, P. (2004). Metadiscourse in academic writing: a reappraisal. Applied Linguistics, 25, (2), 156 - 177.

Khedri, M., Heng, C.S., and Ebrahimi, S.F. (2013). An exploration of interactive metadiscourse markers in academic research article abstracts in two disciplines. Discourse Studies, 15, (3), 319 - 331 .
Kuhi, D. and Mojood, M. (2014). Metadiscourse in newspaper genre: a cross-linguistic study of English and Persian editorials. Procedia - Social and Behavioral Sciences 98, 1046 1055.

Ozdemir, N. O., and Longo, B. (2014). Metadiscourse Use in Thesis Abstracts: A Cross-cultural Study. Procedia - Social and Behavioral Sciences 141, 59 - 63.

Siddique, A.R., Mahmood, M.A., and Iqbal, J. (2018). Metadiscourse analysis of Pakistani English newspaper editorials: a corpus-based study. International Journal of English Linguistics, 8, (1), $146-163$.

Sukma, B.P. and Sujatna, E.T.S. (2014). Interpersonal metadiscourse markers in opinion articles: a study of texts written by Indonesian writers. International Journal of Applied Linguistics \& English Literature, 3, (2), $16-21$.

Tavanpour, N., Goudarzi, Z., and Farnia, M. (2016). Interactional metadiscourse markers in sports news in newspapers: a cross-cultural study of American and Iranian columnists. The Philologist, 1, $1-13$.

*Author(s) Correspondence:

E-mail: anugroho@bundamulia.ac.id 